\title{
Serology unveils decades-long contact of the Iberian hare, Lepus granatensis, with myxoma or antigenically-related virus.
}

\author{
Fábio A. Abade dos Santos ${ }^{1}$, Nuno Santos $^{2}$, Carina Carvalho ${ }^{3}$, Mónica Martinez $^{4}$, \\ Christian Gortazar ${ }^{5}$, Ignacio García-Bocanegra ${ }^{6}$, Margarida Duarte $^{3}$, and Paulo Alves ${ }^{2}$ \\ ${ }^{1}$ University of Lisbon Faculty of Veterinary Medicine \\ ${ }^{2}$ CIBIO-InBIO, Research Centre in Biodiversity and Genetic Resources, Vairão, Portugal \\ ${ }^{3}$ INIAV \\ ${ }^{4}$ Instituto Regional de Investigación y Desarrollo Agroalimentario y Forestal (IRIAF). \\ Centro de Investigación Agroambiental El Chaparrillo, Ciudad Real, Spain \\ ${ }^{5}$ SaBio Instituto de Investigación en Recursos Cinegéticos IREC (UCLM \& CSIC), Ciudad \\ Real, Spain \\ ${ }^{6}$ University of Cordoba Faculty of Veterinary
}

August 23, 2020

\begin{abstract}
The 2018 outbreak of myxomatosis in the Iberian hare (Lepus granatensis), has been hypothesized to originate from a species jump of the rabbit-associated myxoma virus (MYXV), after natural recombination with an unknown poxvirus. Iberian hares were long considered resistant to myxomatosis as no prior outbreaks were reported. To provide insights into the emergence of this recombinant virus (ha-MYXV), we investigated serum samples from 451 Iberian hares (88 live captured, 313 hunted and 50 found dead) collected over two time periods, 1994-1999 and 2017-2019, using a rabbit commercial indirect ELISA after validation, and tested different tissues or sera by a qPCR targeting M0005L/R gene conserved in MYXV and ha-MYXV. The cut-off of ELISA Relative Index $10=6.1$ yielded an estimated positive predictive value of 96.4\% (CI95\% 82.6-98.0\%), by comparison with qPCR positive and negative reference hares. Overall, antibodies were detected in $12.6 \%$ (57/451) of the hares tested, of which $40.3 \%$ (23/57) were also qPCR positive. Antibodies were found in apparently healthy hares sampled in 19941999 ( $n=10$, none MYXV-DNA positive), and in 2017-2019 ( $\mathrm{n}=28$, of which 14\% were MYXV-DNA positive). For the Iberian hares hunted or live trapped, seroprevalence was significantly higher in 2017-2019 (13.0\%, CI95\% 9.2-18.2\%) than in 1994-1999 (5.4\%, CI95\% 3.0-9.6\%) ( $\mathrm{p}=0.005)$, and significantly higher in $2019(\mathrm{p}=0.007)$, being lower during the winter $(\mathrm{p}<0.001)$. While our molecular and serological results show that Iberian hares have been in contact with MYXV or an antigenically similar virus at least since 1994, they also show an increase in seroprevalence in 2018-2019. The more remote contact of hares with MYXV may have occurred with strains that circulated in wild rabbit, or unnoticed strains circulating in Iberian hare populations. This work clearly confirms the circulation of MYXV in the Iberian hare ate least 20 years before the severe virus outbreaks observed in 2018 .
\end{abstract}

Serology unveils decades-long contact of the Iberian hare,Lepus granatensis, with myxoma or antigenically-related virus

Short title: Serologic myxoma virus retrospective in Iberian hare

Fábio A. Abade dos $\operatorname{Santos}^{1,2,3}{ }^{*}$, Nuno Santos ${ }^{4}$, Carina L. Carvalho ${ }^{1}$, Mónica Martinez ${ }^{5}$, Christian Gortázar $^{6}$, Ignacio García-Bocanegra ${ }^{7}$, Margarida Duarte ${ }^{1,2 *}$, Paulo Célio Alves ${ }^{4,8,9 *}$

* Equally contributing authors 
${ }^{1}$ INIAV, IP. National Institute of Agrarian and Veterinarian Research. Av. da República, 2780-143 Oeiras, Portugal

${ }^{2}$ CIISA, Faculty of Veterinary Medicine of Lisbon, Avenida da Universidade Técnica 1300-477 Lisboa. Portugal

${ }^{3}$ Instituto Universitario de Biotecnología de Asturias (IUBA), Departamento de Bioquímica y Biología Molecular, Universidad de Oviedo, Oviedo, Spain.

${ }^{4}$ CIBIO-InBIO, Research Centre in Biodiversity and Genetic Resources, Vairão, Portugal

${ }^{5}$ Instituto Regional de Investigación y Desarrollo Agroalimentario y Forestal (IRIAF). Centro de Investigación Agroambiental El Chaparrillo, Ciudad Real, Spain

${ }^{6}$ SaBio Instituto de Investigación en Recursos Cinegéticos IREC (UCLM \& CSIC), Ciudad Real, Spain

7 Animal Health Department, Faculty of Veterinary, University of Córdoba, Córdoba, Spain

${ }^{8}$ Dep. Biology, Faculty of Science, University of Porto, Porto, Portugal

${ }^{9}$ Wildlife Biology Program, University of Montana, Missoula, USA

\section{Corresponding authors}

Fábio A. Abade dos Santos (fabio.abade@iniav.pt)

Nuno Santos (nuno.santos@cibio.up.pt)

\section{Summary}

The 2018 outbreak of myxomatosis in the Iberian hare (Lepus granatensis), has been hypothesized to originate from a species jump of the rabbit-associated myxoma virus (MYXV), after natural recombination with an unknown poxvirus. Iberian hares were long considered resistant to myxomatosis as no prior outbreaks were reported.

To provide insights into the emergence of this recombinant virus (ha-MYXV), we investigated serum samples from 451 Iberian hares (88 live captured, 313 hunted and 50 found dead) collected over two time periods, 1994-1999 and 2017-2019, using a rabbit commercial indirect ELISA after validation, and tested different tissues or sera by a qPCR targeting $M 0005 L / R$ gene conserved in MYXV and ha-MYXV.

The cut-off of ELISA Relative Index $10=6.1$ yielded an estimated positive predictive value of $96.4 \%$ ( $\left.\mathrm{CI}_{95 \%} 82.6-98.0 \%\right)$, by comparison with qPCR positive and negative reference hares. Overall, antibodies were detected in $12.6 \%(57 / 451)$ of the hares tested, of which $40.3 \%(23 / 57)$ were also qPCR positive. Antibodies were found in apparently healthy hares sampled in 1994-1999 ( $\mathrm{n}=10$, none MYXV-DNA positive), and in 2017-2019 ( $\mathrm{n}=28$, of which 14\% were MYXV-DNA positive). For the Iberian hares hunted or live trapped, seroprevalence was significantly higher in 2017-2019 (13.0\%, $\left.\mathrm{CI}_{95 \%} 9.2-18.2 \%\right)$ than in $1994-1999\left(5.4 \%, \mathrm{CI}_{95 \%}\right.$ $3.0-9.6 \%)(\mathrm{p}=0.005)$, and significantly higher in $2019(\mathrm{p}=0.007)$, being lower during the winter $(\mathrm{p}<0.001)$.

While our molecular and serological results show that Iberian hares have been in contact with MYXV or an antigenically similar virus at least since 1994, they also show an increase in seroprevalence in 2018-2019. The more remote contact of hares with MYXV may have occurred with strains that circulated in wild rabbit, or unnoticed strains circulating in Iberian hare populations. This work clearly confirms the circulation of MYXV in the Iberian hare ate least 20 years before the severe virus outbreaks observed in 2018.

Keywords: emerging disease, Lepus granatensis , Iberian hare, myxomatosis, myxoma virus, recombinant, qPCR, ELISA, Iberian Peninsula

\section{Introduction}

Myxomatosis is caused by infection with the myxoma virus (MYXV), belonging to genus Leporipoxvirus from subfamily Chordopoxvirinae and family Poxviridae. It has a 163 kbp-long dsDNA genome, that/which 
replicates in the cytoplasm of the infected cells (Murphy et al., 1995), and is transmitted mainly by biting arthropods or direct contact with infected animals (Mead-Briggs and Vaughan, 1975).

In the European rabbit (Oryctolagus cuniculus), MYXV high virulent strains induce a severe, often fatal, generalised disease characterised by swollen head, eyelids and ears, blepharoconjunctivitis with mucopurulent ocular and nasal discharge, cutaneous lesions, and inflammation and oedema of the genitalia and perianal skin (Bertagnoli and Marchandeau, 2015; Kerr et al., 2015). Since its intentional introduction in Europe in 1952, myxomatosis became endemic in European rabbit populations (Bertagnoli and Marchandeau, 2015; Villafuerte et al., 2017a). According to the severity of the lesions induced in rabbit, the MYXV strains can be classified in I (higher) to V (lower) virulence grades ( Kerr \& Best, 1998).

Until recently, the European rabbit was the only Iberian lagomorph considered highly susceptible to infection by the MYXV. While sporadic cases of myxomatosis have been reported in brown hares Lepus europaeus (Magallon et al., 1953; Jacotot et al., 1954; Barlow et al., 2014), the endemic and declining Iberian hare (Lepus granatensis ) (Carro and Soriguer, 2017) was considered resilient to MYXV infection, with no confirmed cases of myxomatosis until 2018, when a large outbreak was reported in southwestern Spain (Bocanegra et al., 2019). This outbreak recurred on the subsequent years, and has been spreading throughout the Iberian Peninsula (Carvalho et al., 2020). Between September 2017 and mid-October 2018, within a national Portuguese surveillance program, 80 asymptomatic hunted Iberian hares were investigated for MYXV-DNA, with none testing positive (Duarte, M.D. et al., 2018).

A novel strain of MYXV was genotyped from dead Iberian hares during the 2018 outbreak (Dalton et al., 2019; Pinto et al., 2019; Carvalho et al., 2020).These studies demonstrated a natural recombinant virus (ha-MYXV), which has additional genetic material, hypothesized to have allowed the species jump event, and/or increased virulence for Iberian hares. Although ha-MYXV DNA was detected in few wild rabbits (unpublished data), the rarity of these findings supports the apparent preferential circulation of MYXV and ha-MYXV in rabbits and hares, respectively.

The susceptibility of the Iberian hare to MYXV infection (sensu latu) has only recently been reported, associated with a recombinant virus never described before. However, neither the susceptibility of the hare to MYXV infection, nor the lack of it, has been scientifically investigated.

The aim of this study is to provide insights into the emergence of myxomatosis in the Iberian hare, by assessing the presence of antibodies against MYXV antigens in specimens from Spain and Portugal, before and during the outbreaks reported in 2018.

We performed a retrospective serological survey in samples collected in two periods different periods, with 18 years apart; before the outbreak (1994 to 1999) to investigate the contact of Iberian hare populations with MYXV or MYXV-like viruses in the past, and encompassing the outbreak recorded in 2018. Whenever possible, the serological data was combined with clinical, pathological and molecular information to explore uncovered clues about the recent emergence of highly pathogenic ha-MYXV in Iberian hares.

Given that the origin of this recombinant virus is yet to be explained, several hypotheses are revised and considered in this manuscript.

\section{Material and Methods}

\subsection{Sample collection and serum preparation}

Blood samples were collected from 451 Iberian hares, mostly from central-south-western Iberian Peninsula, coinciding with regions that were covered by research studies in Portugal and Spain, and where the recent myxomatosis infections have been detected. Iberian hares included in the study were either live captured with long nets following drives $(n=88)$, or post-mortem, either hunted (apparently healthy, $n=313$ ), or found dead in the field $(\mathrm{n}=50)$. Live captures and hunting samples were considered in this study as random sampling, contrary to the animals found dead in the field, possibly due to myxomatosis infection. Sampling took place in two time periods: 1994-1999 and 2017-2019 (Table 1). The samples from 2018 and 2019 were collected 
after the emergence of myxomatosis (middle and late 2018 for Spain and Portugal, respectively). Hares were hunted according to the Spanish, Portuguese and European legislation. Thus, no animal was sacrificed for the purpose of this study.

Blood collection from live hares was obtained by venepuncture of the marginal ear vein or the external jugular vein (Abade dos Santos et al., 2019), and from dead animals by cardiac puncture. Blood was transferred into plain tubes, centrifuged for $10 \mathrm{~min}$ at $1,500 \mathrm{~g}$ at $4^{\mathrm{O}} \mathrm{C}$ and the serum was preserved at $-20^{\circ} \mathrm{C}$ until analysis.

\subsection{Indirect ELISA}

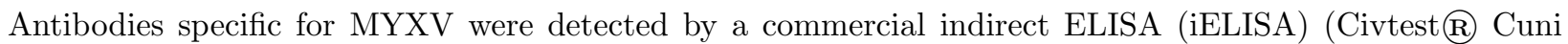
Mixomatosis, Hipra, Girona, Spain), following manufacturer's instructions. Antigens consisted of MYXV Sanarelli strain and protein G-horseradish peroxidase was used as conjugate. Briefly, serum samples were added to the plate $(100 \mu \mathrm{l} /$ well $)$ at a dilution of 1:40 in dilution solution and incubated for $20 \mathrm{~min}$ at $37^{\circ} \mathrm{C}$. After three washes with $300 \mu \mathrm{l}$ washing solution/well, protein G-horseradish peroxidase conjugate was added $(100 \mu \mathrm{l} /$ well $)$ and incubated for $20 \mathrm{~min}$ at $37^{\circ} \mathrm{C}$. The plate was washed three times and $3,3^{\prime}, 5,5^{\prime}-$ Tetramethylbenzidine (TMB) was added $(100 \mu \mathrm{l} /$ well $)$ as liquid substrate and incubated for $10 \mathrm{~min}$ at room temperature. The reaction was stopped with $100 \mu \mathrm{l} /$ well of $\mathrm{H}_{2} \mathrm{SO}_{4}$ and the optical density (OD) measured in a spectrophotometer at $450 \mathrm{~nm}$. Positive and negative controls and samples were tested in duplicate in each plate. Results were expressed as Relative Index 10 (RI10) using the formula:

$$
R I 10=\left[\frac{\text { Mean OD sample }- \text { Mean OD negative control }}{\text { Mean OD positive control }- \text { Mean OD negative control }}\right] \times 10
$$

\subsection{ELISA cut-off estimation}

A subset of the sample comprising positive $(n=51)$ and negative $(n=114)$ sera from symptomatic and asymptomatic hares that tested positive and negative for MYXV-DNA by qPCR-M000.5R/L, was used to assess the ELISA cut-off using the R (R Development Core Team, 2008) package 'OptimalCutpoints' (López-Ratón et al., 2014). The cut-off was estimated based on the criteria of a positive predictive value (PPV) $>0.95$, to guarantee that the animals testing positive were truly exposed to MYXV or to an antigenically related virus.

To further support the estimated cut-off, we performed a finite mixture analysis of log-transformed RI10 data, to estimate the mean and standard deviation of the negative population (Peel et al., 2014). Finite mixture models allow to characterize the distributions of subgroups within bimodal datasets (Benaglia et al., 2009), thus being an alternative tool to estimate the cut-off of serological tests in the absence of reference tests (Peel et al., 2014). Finite mixture models were implemented using the expectation-maximization algorithm for mixtures of univariate normal distributions, from the package 'mixtools' (Benaglia et al., 2009) in R (R Development Core Team, 2017). The proportion of the seronegative subgroup was set at 1-prevalence and the mean of each subgroup was defined from the mean logRI10 of the subgroup in which molecular testing was performed.

\subsection{Necropsy and molecular diagnosis}

Necropsies were carried out at the Nacional Institute of Agrarian and Veterinary Research, Portugal, and at the Veterinary Science College, Universidad de Córdoba and at the Instituto de Investigación en Recursos Cinegéticos (UCLM \& CSIC), Spain.

Tissue samples from hares collected in Portugal, were analysed according to Duarte et al. (Duarte et al., 2014). The diploid targeted gene M000.5L/R is present in the MYXV and MYXV-like genomes, but not in other leporipoxviruses, such as Shope Fibroma Virus. For nucleic acid extraction, fresh samples of liver, spleen and palpebra were homogenised at $20 \%$ (w/v) with phosphate buffered saline (PBS) and clarified at $3000 \mathrm{~g}$ for 5 min at $4^{\circ} \mathrm{C}$. Sera was diluted at 1:4 in PBS. Total DNA was extracted from $200 \mu$ l of the clarified 
tissue supernatants and diluted serum samples, using the MagAttract 96 cador Pathogen Kit in a BioSprint 96 nucleic acid extractor (Qiagen, Hilden, Germany), according to the manufacturer's protocol.

Hare samples collected in Spain were analysed according to García-Bocanegra et al. (Bocanegra et al., 2019). At the Central Veterinary Laboratory in Algete (Spanish National Reference Animal Health Laboratory), total DNA was extracted with the MagAttract@ 96 Cador $\AA$ Pathogen Kit (QIAGEN, Germany) following the manufacturer's instructions. For the detection of DNA of both the classical MYXV strains and the novel ha-MYXV isolate, a conserved region of the M071L or M000.5L/R gene was amplified by PCR or real time PCR, respectively, as previously described (Cavadini et al., 2010; Duarte et al., 2014; Dalton et al., 2019).Using TaKaRa LA Taq DNA polymerase (TaKaRa, Japan), a specific ha-MYXV PCR was carried out with primers M009L (Dalton et al., 2019).

\subsection{Statistical analysis}

Generalised linear models (GLM) were used to assess the effect of the independent variables sex, age, year, season and type of sampling on the iELISA test results. The iELISA results considered were positive/negative, thus a binomial GLM with logit link was used. The reference classes of the independent factors were set as females, adults, randomly collected samples, year 2017, month October and season autumn. Collinearity was checked by estimating the Variance Inflation Factor with a threshold of 3. A one-tailed 2-sample test for equality of proportions without continuity correction was used to compare seroprevalence between periods. Significance was set at 0.05 .

Statistical analysis was performed in R (R Development Core Team, 2017). Maps were produced in QGIS 2.6.1 Brighton software (QGIS Development Team, 2011).

\section{Results}

\subsection{Cut-off of iELISA}

Assuming the molecular detection of MYXV/ha-MYXV as reference diagnostic test, the cut-off RI10 = 6.1 yielded an estimated positive predictive value of $96.4 \%\left(\mathrm{CI}_{95 \%} 82.6-98.0 \%\right)$, a specificity of $99.1 \%\left(\mathrm{CI}_{95 \%}\right.$ $95.2-100 \%)$ and a sensitivity of $52.9 \%\left(\mathrm{CI}_{95 \%} 38.5-67.1 \%\right)$. The area under the ROC curve was estimated at $79.2 \%\left(\mathrm{CI}_{95 \%} 69.7-88.7 \%\right)$. The finite mixture model estimated the seronegative subgroup as a normal distribution of RI10 with mean $=0.803$ and standard error $=1.714$. Under the assumption of normality of the log transformed RI10 seronegative data, the cut-off RI10=6.1 yielded an estimated specificity of $99.9 \%$.

\subsection{Seroprevalence and presence of viral DNA}

The results obtained from the serological tests and molecular analysis for each year are shown in Table 2, Fig.1 and Fig.2. Antibodies recognising MYXV antigens were detected in 57 Iberian hares. Interestingly, $5.4 \%\left(\mathrm{CI}_{95 \%}\right.$ 3.0-9.6\%) of the samples randomly collected in 1994-1997, were seropositive (Table 2). In 2017, $1.7 \%$ of sera $\left(\mathrm{CI}_{95 \%} 0.3-8.9 \%\right)$ were seropositive, while in $2018-2019$ the seropositivity was $17.4 \%\left(\mathrm{CI}_{95 \%}\right.$ 12.3-24.2\%). The seropositivity in the found-dead subset of the sample was $39.1 \%\left(\mathrm{CI}_{95 \%} 22.2-59.2 \%\right)$, more than double than in the randomly collected sera subset.

For the samples collected between 1994-1999, only blood serum was available. Sera were diluted 1:4 in PBS prior extraction to avoid inhibition. MYXV-DNA was detected in four samples from 1994-1999 (all corresponding to seronegative hares), in very low quantities as expected (Cq values around 35.0 according with (Duarte et al., 2014)). Regarding the samples collecter over 2017-2019, higher RI10 values were associated to the qPCR positive samples (Fig. 3, green dots in left graph). Contrarily, lower values of RI10 were observed in the group of qPCR negative and non-tested hares (Fig. 3, red and blank dots in right graph).

Seropositive samples were detected in two out of the five administrative units included in the study in 1994-1999 as well as in 11 of 20 units included in 2017-2019 (Fig. 4).

\subsection{Determinants of seropositivity}


For the Iberian hares randomly sampled (hunted or live trapped), seroprevalence was significantly higher in the year of $2019\left(\beta=2.9058, p=0.00^{7}\right)$ and was lower during the winter $(\beta=-2.1551, p<0.001)$, compared to the other seasons (Fig. 2 B). No differences were found between sex and age classes. Seroprevalence was significantly higher in $2017-2019\left(12.9 \%, \mathrm{CI}_{95 \%} 9.1-18.0 \%\right)$ than in $1994-1999\left(5.4 \%, \mathrm{CI}_{95 \%} 3.0-9.6 \%\right)$ $(p=0.005)$.

\section{Discussion}

This study provides strong evidences for the exposure of Iberian hare populations to MYXV or other virus antigenically similar to MYXV more than two decades before the occurrence of the first reported outbreak, and thus new insights into the emergence of a new natural recombinant, and highly pathogenic, ha-MYXV strain in Iberian hares in mid-2018 (Bocanegra et al., 2019; Dalton et al., 2019; Pinto et al., 2019; Carvalho et al., 2020).

To assess the earlier circulation of MYXV or other MYXV-like viruses and contact with Iberian hare populations we used and validated a commercial indirect ELISA originally developed to detect rabbit antibodies that recognise MYXV antigens to detect antibodies in hares, using protein G as conjugate. Whenever possible samples were investigated for MYXV-DNA. Although rabbits and hares belong to the same taxonomic family Leporidae, the relative affinity of protein G towards Iberian hare's immunoglobulins (Ig) has not been estimated and compared to the affinity towards rabbit Ig. In fact, there is a significant difference in the $\mathrm{G}$ protein affinity towards Ig from different species (Biolabs, 2020). Furthermore, the iELISA includes rabbit positive and negative control sera. Since a dissimilar affinity to the Iberian hare Ig could affect the performance and outcome of the iELISA, the adequacy of the test for hare sera was evaluated and the cut-off for positivity was firstly estimated.

It was then necessary to ensure that the hares testing positive had been truly exposed to the myxoma virus or an antigenically similar virus. We thus aimed for a cut-off maximising the positive predictive value of the serological test (iELISA). The qPCR results for ha-MYXV in healthy hares and myxoma-affected hares collected after the 2018 emergence, were used to assign the "infected/non-infected" reference categories. While molecular tests detect viral DNA, which is assumed to mean infection, the serological tests reveal the presence of specific antibodies, which last longer than viremia, as assessed in European rabbits (Kerr, 2012). The mismatch between the timeframes of viral positivity (earlier and shorter) and antibody positivity (later and long-lasting) may therefore have introduced some noise in our data.

The selected cut-off was further supported by finite mixture models, which do not assume a reference test. Under the assumption of normality of the log transformed IR10 of the seronegative subset of our sample, $99.9 \%$ of the estimated seronegative population would be correctly assigned by the iELISA, using the selected cut-off. The iELISA with a cut-off RI10 $=6.1$ yielded a good performance, as shown by an estimated positive predictive value of $96.4 \%\left(\mathrm{CI}_{95 \%} 82.6-98.0 \%\right)$ and a specificity of $99.1 \%\left(\mathrm{CI}_{95 \%} 95.2-100 \%\right)$. The sensitivity of the test was moderate $\left(52.9 \%, \mathrm{CI}_{95 \%} 38.5-67.1 \%\right)$, which is due to most $(55.8 \%)$ of the qPCR positive Iberian hares not having detectable antibodies recognising MYXV antigens. Therefore, the overall seroprevalence is probably slightly underestimated. Hares infected with MYXV but without detectable antibodies may represent the initial stage of infection or a hyperacute myxomatosis presentation (Carvalho et al., 2020; García-Bocanegra et al., 2019). Either way, the iELISA allows a high degree of certainty in establishing that a hare with detectable antibodies had contacted and become infected by virus identical or antigenically similar to MYXY.

Given the large scale of the current outbreak of myxomatosis in Iberian hares, it is not surprising that the seroprevalence in randomly collected samples was higher in 2018-2019, when compared to 1994-1999 (Fig. 2). In fact, the GLM identified 2019 as the year having significantly higher seroprevalence (21.5\%, $\mathrm{CI}_{95 \%}$ 13.3-33.0\%) (Fig. 2). Interestingly, the year 1999 showed non-significant statistically elevated values of seroprevalence (10.0\%, $\mathrm{CI}_{95 \%} 4.4-21.4 \%$ ), not associated with any known reported case of mortality. This lack of reporting could be due to deficient sanitary surveillance in Iberian hare during the 1990's (Leighton et al., 1995). Sanitary surveillance in Europe, and particularly in the Iberian Peninsula, has been improving 
in the last decades, despite still far from an optimized system.

Despite being recognised that some hare species other than Lepus granatensis are susceptible to myxomatosis (Magallon et al., 1953; Jacotot et al., 1954; Barlow et al., 2014), the scarcity of scientific evidence regarding the putative infection of Iberian hare by MYXV give room to different explanations. Iberian hares have for long been considered refractory to infection by the MYXV strains, contrasting with European rabbit where a severe disease usually develops (Fig. 5A) (Wibbelt and Frolich, 2005). Others have suggested that the Iberian hare could be naturally resistant to the infection (Fig. 5C) (Fenner and Fantini, 1999). However, no serological evidences were provided to support or exclude any of these theories.

Our results corroborate the serology data published very recently (García-Bocanegra et al., 2020) and report for the first time the presence of antibodies recognising MYXV antigens in Iberian hare populations since at least 1996, supporting the theory of enduring circulation of MYXV, or a virus antigenically similar to MYXV, in this host species, possibly in unapparent forms of disease that justify the lack of published reports. In infected domestic rabbits, IgM can be detected 5-6 days post-infection and during the following 30 to 40 days, whereas IgG peaks at day 20 to 30 and can be detected up to 2 years (OIE Terrestrial Manual, 2018). This hypothesis is further reinforced by the detection of myxoma virus-specific DNA (gene M005) that does not differentiate from ha-MYXV.

The relatively high seropositivity in 1999 suggests that, in this year, the sampled hare populations had eventually more contact with a virus antigenically identical or similar to MYXV, which could have been a virulent MYXV strain grade I or II. In certain conditions, such as immunosuppression induced by pathogens, as the recently described gammaherpesvirus LeHV-5 (Abade dos Santos et al., 2020), hares may eventually become more susceptible to rabbit MYXV (Fig. 5B). Another possibility is that ha-MYXV was already circulating unnoticed in Iberian hares (Fig. 5E). Also, the recombination event that generated ha-MYXV may have involved an intermediate host (Fig. 5C), similarly to many emerging viruses (e.g. SARS-CoV1, MERS-CoV, SRAS-CoV-2). Rather than a recent species jump from rabbit to hare, our results support the possibility of a genetic change in a MYXV strain that was already circulating unnoticed in the hare populations (Fig. 5E). An increased virulence of this strain would lead to the recent outbreaks, as previously suggested (Dalton et al., 2019; Pinto et al., 2019). The possibility that ha-MYXV originated from a distinct hare MYXV that was already circulating unnoticed in wild hare populations for decades under subclinical forms of disease, would explain myxomatosis never being reported before in hares (Fig. 5F).

The higher seroprevalence in our sample during the spring/summer suggests seasonal transmission like that of MYXV in European rabbits, possibly also mediated by arthropod vectors (García-Bocanegra et al., 2010). The seroprevalence found in the Iberian hare is much lower than the seroprevalence reported in European rabbits (Ferreira et al., 2009; Boag et al., 2013), which can be justified by the high fatality rate of haMYXV infection in hares (Bocanegra et al., 2019). Also, the Iberian hare is a more solitary species than the gregarious European rabbit, attaining lower densities (Gortazar et al., 2007), which could hinder MYXV transmission (Villafuerte et al., 2017b). Also, the reproductive characteristics of hares, with less and smaller litters compared to the European rabbit (Alves et al., 2002; Gonçalves et al., 2002) introduce fewer susceptible juveniles to the population, which may lead to greater containment of outbreaks due to the existence of fewer susceptible animals (García-Bocanegra et al., 2010).

The case fatality rate of the ha-MYXV infection in Iberian hares in Spain has been estimated at $69.2 \%$ (García-Bocanegra et al., 2019). We detected a significant proportion of the hares as qPCR-negative but antibody-positive. Given the lack of skin lesions, liver and lungs were also used to investigate MYXV-DNA in apparently healthy hare tissues. However, since low titres are generally observed in these organs (liver, spleen lungs), even during active MYXV infection (Kerr et al., 2015), one cannot exclude that some of the MYXV qPCR negative results may be false negatives at initial stages of infection, before clinical signs become apparent.

The detection of viral MYXV-DNA in four serum samples from 1997 collected in Alcochete, Portugal, strongly corroborates the conclusions based in serological data. 
In conclusion, despite the origin of the ha-MYXV still being unclear, our study shows the long-term circulation of virus antigenically similar to MYXV in Iberian hare populations and support the hypothesis of a recent increase in virulence of MYXV strain or antigenically similar strains already circulating in hares, that could have caused the ongoing outbreak. Furthermore, we describe and evaluate the performance of a commercial serological ELISA to detect MYXV antibodies in hare sera, which proved reliable and may contribute to extend the knowledge on the epidemiology of myxomatosis in hares. Our results also highlight the need to continue and improve sanitary surveillance of this neglected game species.

\section{Acknowledgements}

This work was financed by the Fundo Florestal Permanente, Government of Portugal, (Project + Coelho 2, ref. 2019014300001, as part of the Action Plan for the Control of Rabbit Viral Haemorrhagic Disease (Dispatch no. 4757/2017 of 31 May) and by the Spanish Ministry of Science and Innovation (PID2019-111080RB-C21). Fundação para a Ciência e Tecnologia (FCT) funded Nuno Santos (grant SFRH/BPD/116596/2016) and Fábio A. Abade dos Santos (SFRH/BD/137067/2018). The Centre for Interdisciplinary Research in Animal Health (CIISA) from the Faculty of Veterinary Medicine (University of Lisbon) also contributed to this study (CIISA-UIDP/CVT/00276/2020). MMH is currently funded by Junta de Comunidades de Castilla-La Mancha and the European Regional Development Fund (SBPLY/17/180501/000514).

\section{Ethics statement}

The authors confirm that the ethical policies of the journal, as noted on the journal's author guidelines page, have been adhered to. No ethical approval was required as no animal was killed for the purpose of this study.

\section{Conflict of interest}

The authors declare no competing interests.

\section{Data Sharing}

The data that support the findings of this study are available from the corresponding author upon reasonable request.

\section{References}

Abade dos Santos, F.A., C.L. Carvalho, M.C. Peleteiro, S. Gabriel, R. Patrício, F.A. Abade, C.L. Carvalho, M.C. Peleteiro, S.I. Gabriel, R. Patrício, J. Carvalho, M. V Cunha, and M.D. Duarte, 2019: Blood collection from the external jugular vein of Oryctolagus cuniculus algirus sedated with midazolam : live sampling of a subspecies at risk Blood collection from the external jugular vein of Oryctolagus cuniculus algirus sedated with midazolam : live. Wildlife Biol.1 , DOI: 10.2981/wlb.00588.

Abade dos Santos, F.A., M. Monteiro, A. Pinto, C.L. Carvalho, M.C. Peleteiro, P. Carvalho, P. Mendonca, T. Carvalho, and M.D. Duarte, 2020: First description of a herpesvirus infection in genus Lepus. PLoS One 14 , 1-20, DOI: 10.1371/journal.pone.0231795.

Alves, P.C., H. Goncalves, M. Santos, and A. Rocha, 2002: Reproductive biology of the Iberian hare, Lepus granatensis, in Portugal.Mamm. Biol. 67, 358-371.

Barlow, A., K. Lawrence, D. Everest, A. Dastjerdi, C. Finnegan, and F. Steinbach, 2014: Confirmation of myxomatosis in a European brown hare in Great Britain. Vet. Rec. 175 , 75-76, DOI: 10.1136/vr.g4621.

Benaglia, T., D. Chauveau, D. Hunter, and D. Young, 2009: mixtools: An R Package for Analyzing Finite Mixture Models. J. Stat. Software. Univ. California. 1-23.

Bertagnoli, S., and S. Marchandeau, 2015: The myxoma virus. Rev. Sci. Tech. Off. Int. Epiz. 34 , $549-556$. 
Biolabs, 2020: Affinity of Protein A/G for IgG Types from Different Species [Online] Available at https://www.neb.com/tools-and-resources/selection-charts/affinity-of-protein-ag-for-igg-types-fromdifferent-species (accessed May 1, 2020).

Boag, B., A.D. Hernandez, and I.M. Cattadori, 2013: Observations on the epidemiology and interactions between myxomatosis , coccidiosis and helminth parasites in a wild rabbit population in Scotland. 557-562, DOI: $10.1007 / \mathrm{s} 10344-013-0704-0$.

Bocanegra, I.G., L. Camacho-Sillero, M.A. Risalde, K. Dalton, J. Caballero-Gomez, M. Aguero, I. Zorrila, and F. Gomez-Guillamon, 2019: First outbreak of myxomatosis in Iberian hares ( Lepus granatensis ).Transbound. Emerg. Dis. 1-5, DOI: 10.1111/tbed.13289.

Carro, F., and R.C. Soriguer, 2017: Long-term patterns in Iberian hare population dynamics in a protected area (Donana National Park) in the SW Iberian Peninsula: effects of wheather conditions and plant cover.Integr. Zool. DOI: 10.1111/1749-4877.12212.

Carvalho, C.L., F.A. dos Santos, M. Monteiro, P. Carvalho, P. Mendonca, and M.D. Duarte, 2020: First cases of myxomatosis in Iberian hares (Lepus granatensis) in Portugal. Vet. Rec. Case Reports8, DOI: 10.1136/vetreccr-2019-001044.

Cavadini, P., G. Botti, I. Barbieri, A. Lavazza, and L. Capucci, 2010: Molecular characterization of SG33 and Borghi vaccines used against myxomatosis. Vaccine 28, 5414-5420, DOI: 10.1016/j.vaccine.2010.06.017.

Dalton, K.P., J.M. Martin, I. Nicieza, A. Podadera, D. Llano, R. Casais, S. Gimenez, I. Badiola, M. Aguero, M. Duran, D. Buitrago, L.J. Romero, E. Garcia, and F. Parra, 2019: Myxoma virus jumps species to the Iberian hare. Transbound. Emerg. Dis. tbed.13296, DOI: 10.1111/tbed.13296.

Duarte, M.D., S.C. Barros, A.M. Henriques, M.T. Fagulha, F. Ramos, T. Luis, and M. Fevereiro, 2014: Development and validation of a real time PCR for the detection of myxoma virus based on the diploid gene M000 . 5L / R. J. Virol. Methods 196 , 219-224, DOI: 10.1016/j.jviromet.2013.11.014.

Duarte, M.D., C.L. Carvalho, F.A. Abade dos Santos, J. Gomes, P.C. Alves, P.J. Esteves, J. Abrantes, A.M. Lopes, M. P., A. Serronha, N. Santos, P.T. Santos, Y. Vaz, J. Carvalho, F.C. Pinto, J. Amaro, and M. V. Cunha, 2018: +Coelho: Avaliacao Ecossanitaria das Populacoes Naturais de Coelho Bravo Visando o Controlo da Doenca Hemorragica Viral. .

Fenner, F., and B. Fantini, 1999: History of Myxomatosis - an Experiment in Evolution.CABI., In: Biological Control of Vertebrate Pests. New York, USA.

Ferreira, C., E. Ramirez, F. Castro, P. Ferreras, P.C. Alves, S. Redpath, and R. Villafuerte, 2009: Field experimental vaccination campaigns against myxomatosis and their effectiveness in the wild. Vaccine $\mathbf{2 7}$, 6998-7002, DOI: 10.1016/j.vaccine.2009.09.075.

Garcia-Bocanegra, I., L. Camacho-Sillero, J. Caballero-Gomez, M. Aguero, F. Gomez-Guillamon, J. RuizCasas, J. Diaz-Cao, E. Garcia, M. Ruano, and R. Haza, 2020: Monitoring of emerging myxoma virus epidemics in Iberian hares (. Transbound. Emerg. Dis. DOI: 10.1111/tbed.13781.

Goncalves, H., P.C. Alves, and A. Rocha, 2002: Seasonal variation in the reproductive activity of the wild rabbit (Oryctolagus cuniculus algirus) in a Mediterranean ecosystem. Wildl. Res. 29 , 165-173, DOI: 10.1071/WR00048.

Gortazar, C., J. Millan, P. Acevedo, M.A. Escudero, J. Marco, and D.F. de Luco, 2007: A Large-scale Survey of Brown Hare Lepus Europaeus and Iberian Hare L. Granatensis Populations at the Limit of Their Ranges. Wildlife Biol. 13 , 244-250, DOI: 10.2981/0909-6396(2007)13[244:alsobh]2.0.co;2.

Jacotot, H., A. Vallee, and B. Virat, 1954: Sur un cas de myxomatose chez le lievre. Ann. l'Institut Pasteur $86,105-107$. 
Kerr, P.J., 2012: Myxomatosis in Australia and Europe: A model for emerging infectious diseases. Antiviral Res. 93, 387-415, DOI: 10.1016/j.antiviral.2012.01.009.

Kerr, P.J., and S.M. Best, 1998: Myxoma virus in rabbits Myxoma virus and myxomatosis biological control for the Myxomatosis in rabbits in Australia : development of resistance associated with.Rev.sci.tech.Off.int.Epiz. 7 , 256-268.

Kerr, P.J., J. Liu, I. Cattadori, E. Ghedin, A.F. Read, and E.C. Holmes, 2015: Myxoma virus and the leporipoxviruses: An evolutionary paradigm. Viruses 7 , 1020-1061, DOI: 10.3390/v7031020.

Leighton, F.A., M. Artois, L. Capucci, D. Gavier-Widen, and J.P. Morisse, 1995: Antibody response to rabbit viral haemorrhgic disease virus in red foxes (Vulpes vulpes) consuming livers of infected rabbits (Oryctolagus cuniculus). J. Wildl. Dis. 31, 541-544.

Lopez-Raton, M., M.X. Rodriguez-Alvarez, C. Cadarso-Suarez, and F. Gude-Sampedro, 2014: OptimalCutpoints : An R Package for Selecting Optimal Cutpoints in Diagnostic Tests. J. Stat. Softw.61 .

Magallon, P., and J. Bazin, 1953: La myxomatose du lievre. Bull. l'Office Int. des Epizoot. 39 , 765-769.

Mead-Briggs, A.R., and J.A. Vaughan, 1975: The differential transmissibility of myxoma virus strains of differing virulence grades by the rabbit flea Spilopsyllus cuniculi ( Dale )*. J.Hyg.75, 237.

Murphy, F.A., C.M. Fauquet, D.H.L. Bishop, S.A. Ghabrial, A.W. Jarvis, G.P. Martelli, M.A. Mayo, and M.. Summers, 1995: Virus taxonomy: classification and nomenclature of Viruses. . Springer Verlag, Vienna, Austria: Sixth report of the International Committee for the Taxonomy of Viruses. Archives of Virology, Suppl. 10.

OIE Terrestrial Manual, 2018: Myxomatosis, pp. 1371-1388. In: Lagomorpha.

Peel, A.J., J.R.C. Pulliam, A.D. Luis, R.K. Plowright, T.J. O'Shea, D.T.S. Hayman, J.L.N. Wood, C.T. Webb, and O. Restif, 2014: The effect of seasonal birth pulses on pathogen persistence in wild mammal populations. Proc. R. Soc. B Biol. Sci. 281 , 20132962-20132962, DOI: 10.1098/rspb.2013.2962.

Pinto, A., A.L. De Matos, M. Abrantes, S. Kraberger, M.A. Risalde, C. Gort, G. Mcfadden, A. Varsani, and P.J. Esteves, 2019: Genetic Characterization of a Recombinant Myxoma Virus in the Iberian Hare ( Lepus granatensis ). Viruses 11, 1-16, DOI: 10.3390/v11060530.

Villafuerte, R., F. Castro, E. Ramirez, I. Cotilla, F. Parra, M. Delibes-Mateos, P. Recuerda, and C. Rouco, 2017a: Large-scale assessment of myxomatosis prevalence in European wild rabbits (Oryctolagus cuniculus) 60 years after first outbreak in Spain. Res. Vet. Sci. DOI: : 10.1016/j.rvsc.2017.05.014.

Villafuerte, R., F. Castro, E. Ramirez, I. Cotilla, F. Parra, M. Delibes-Mateos, P. Recuerda, and C. Rouco, 2017b: Large-scale assessment of myxomatosis prevalence in European wild rabbits (Oryctolagus cuniculus) 60 years after first outbreak in Spain. Res. Vet. Sci.114, 281-286, DOI: 10.1016/j.rvsc.2017.05.014.

Wibbelt, G., and K. Frolich, 2005: Infectious Diseases in European Brown Hare (lepus europaeus). Wildl. Biol. Pract. 1, DOI: 10.2461/wbp.2005.1.11.

Table 1. Sex and age classes descriptive statistics of the Iberian hares analysed in this study. Number of hares analysed in 1994-1999 and 2017-2019, by sex (F-female; M-male) and age classes (J-juveniles, A-adults).

\begin{tabular}{llllllll}
\hline Sampling methods & Sampling methods & Total & $\mathbf{1 9 9 4 - 1 9 9 9}$ & $\mathbf{1 9 9 4 - 1 9 9 9}$ & $\mathbf{1 9 9 4 - 1 9 9 9}$ & $\mathbf{1 9 9 4 - 1 9 9 9}$ & $\mathbf{1 9 9 4 - 1 9 9}$ \\
& & & $\mathbf{F}$ & $\mathbf{M}$ & $\mathbf{N D}$ & $\mathrm{J}$ & $\mathrm{A}$ \\
Live & & 88 & 24 & 40 & 0 & 15 & 49 \\
Post-mortem & Drives & 313 & 3 & 4 & 115 & 0 & 7 \\
\multirow{2}{*}{ Total } & Hunted & 50 & 0 & 0 & 0 & 0 & 0 \\
\hline
\end{tabular}


Table 2. Summary of the serological, molecular and clinical results in hares by year of sampling. Serological status presented as seropositive $(\mathrm{Ab}+)$ or seronegative $(\mathrm{Ab}-)$ for anti-MYXV antibodies

\begin{tabular}{|c|c|c|c|c|c|c|c|c|c|c|c|c|c|}
\hline \multicolumn{14}{|c|}{$\begin{array}{l}\text { Laboratory } \\
\text { test } \\
\text { re- }\end{array}$} \\
\hline & $\mathrm{Ab}+$ & Ab- & $\mathrm{Ab}+$ & Ab- & $\mathrm{Ab}+$ & Ab- & $\mathbf{A b}+$ & Ab- & $\mathbf{A b}+$ & Ab- & $\mathrm{Ab}+$ & Ab- & $\mathrm{Ab}-$ \\
\hline \multicolumn{2}{|c|}{$\begin{array}{l}\text { Macroscop } \\
\text { le- } \\
\text { sions } \\
\text { present }\end{array}$} & nd & nd & nd & nd & nd & nd & nd & nd & nd & nd & nd & nd \\
\hline $\begin{array}{l}\text { MYXV } \\
\text { pos- } \\
\text { i- } \\
\text { tive } \\
\text { qPCR }\end{array}$ & nd & nd & nd & nd & 0 & 4 & nd & nd & nd & nd & nd & nd & 16 \\
\hline $\begin{array}{l}\text { MYXV } \\
\text { neg- } \\
\text { a- } \\
\text { tive } \\
\text { qPCR }\end{array}$ & nd & 30 & 1 & 21 & 2 & 56 & 2 & 20 & nd & nd & 1 & 59 & 0 \\
\hline $\begin{array}{l}\text { Not } \\
\text { tested } \\
\text { by } \\
\text { qPCR }\end{array}$ & 0 & 0 & 0 & 0 & 0 & 0 & 0 & 0 & 0 & 0 & 5 & 45 & nd \\
\hline $\begin{array}{l}\text { Ab } \\
\text { posi- } \\
\text { tive/Tot } \\
\text { sample }\end{array}$ & $\begin{array}{l}0 / 30 \\
(0 \%) \\
\text { al }\end{array}$ & $\begin{array}{l}0 / 30 \\
(0 \%)\end{array}$ & $\begin{array}{l}1 / 22 \\
(4.5 \%)\end{array}$ & $\begin{array}{l}1 / 22 \\
(4.5 \%)\end{array}$ & $\begin{array}{l}2 / 62 \\
(3.22 \%)\end{array}$ & $\begin{array}{l}2 / 62 \\
(3.22 \%)\end{array}$ & $\begin{array}{l}2 / 22 \\
(9.09)\end{array}$ & $\begin{array}{l}2 / 22 \\
(9.09)\end{array}$ & $\begin{array}{l}5 / 50 \\
(10.0 \%)\end{array}$ & $\begin{array}{l}5 / 50 \\
(10.0 \%)\end{array}$ & $\begin{array}{l}1 / 60 \\
(1.7 \%)\end{array}$ & $\begin{array}{l}1 / 60 \\
(1.7 \%)\end{array}$ & $\begin{array}{l}25 / 1 \\
(20 .\end{array}$ \\
\hline $\begin{array}{l}\text { Ab } \\
\text { posi- } \\
\text { tive / } \\
\text { Ran- } \\
\text { domly } \\
\text { col- } \\
\text { lected } \\
\text { samples }\end{array}$ & $\begin{array}{l}0 / 30 \\
(0 \%)\end{array}$ & $\begin{array}{l}0 / 30 \\
(0 \%)\end{array}$ & $\begin{array}{l}1 / 22 \\
(4.5 \%)\end{array}$ & $\begin{array}{l}1 / 22 \\
(4.5 \%)\end{array}$ & $\begin{array}{l}2 / 62 \\
(3.2 \%)\end{array}$ & $\begin{array}{l}2 / 62 \\
(3.2 \%)\end{array}$ & $\begin{array}{l}2 / 22 \\
(9.1 \%)\end{array}$ & $\begin{array}{l}2 / 22 \\
(9.1 \%)\end{array}$ & $\begin{array}{l}5 / 50 \\
(10 \%)\end{array}$ & $\begin{array}{l}5 / 50 \\
(10 \%)\end{array}$ & $\begin{array}{l}1 / 60 \\
(1.7 \%)\end{array}$ & $\begin{array}{l}1 / 60 \\
(1.7 \%)\end{array}$ & $\begin{array}{l}13 / \mathrm{S} \\
(14 .\end{array}$ \\
\hline
\end{tabular}

nd - no data available

\section{Figure captions}

Figure 1 . Van diagram with the iELISA and $q P C R$ results for the 451 serum samples analysed.

Figure 2. Seroprevalence in Iberian hares by year (A) and season (B). Seroprevalence includes only results from hares randomly sampled (hunted or live captured), showing the proportion of the sample with antibodies recognizing myxoma virus antigens with 95\% confidence interval.

Figure 3. Dot graph with the RI10 values from serum samples collected in different years. The left graph (A) refers to data from serum samples collected from hunted or live trapped hares. The right graph (B) 
refers to data from found dead hares' serum samples. The two horizontal lines point out the IR value, the lower line representing the original cut-off of iELISA (IR=2.0) and upper line (IR 6.1) indicates the adjusted ELISA cutoff value. M- macroscopic lesions compatible with MYXV infection (no qPCR results available), $N$-negative in $q P C R, P$-positive in $q P C R, N D$-no data available on the $q P C R$ test.

Figure 4. Sample size and seropositivity by administrative units in 1994-1999 and 2017-2019. A) Number of Iberian hares sampled; B) Administrative units with seropositive Iberian hares, considering the whole sample. Administrative units are districts in Portugal and provinces in Spain.

Figure 5. Hypotheses for Iberian hare susceptibility to $M Y X V$ and MYXV-related viruses. A-Hares are not susceptible to infection by MYXV strains B-Hares are susceptible to MYXV if exposed to high infectious doses; $C$ - ha-MYXV emerged in hares after a species jump event, involving or not, an intermediate host; $D$ Hares are infected by MYXV, but develop subclinical disease; E-ha-MYXV emerged in hares infected with rabbit strains, by a recombination event that increased virulence of the virus towards hares; F-ha-MYXV emerged in hares from a strain that has circulated unnoticed in the population.

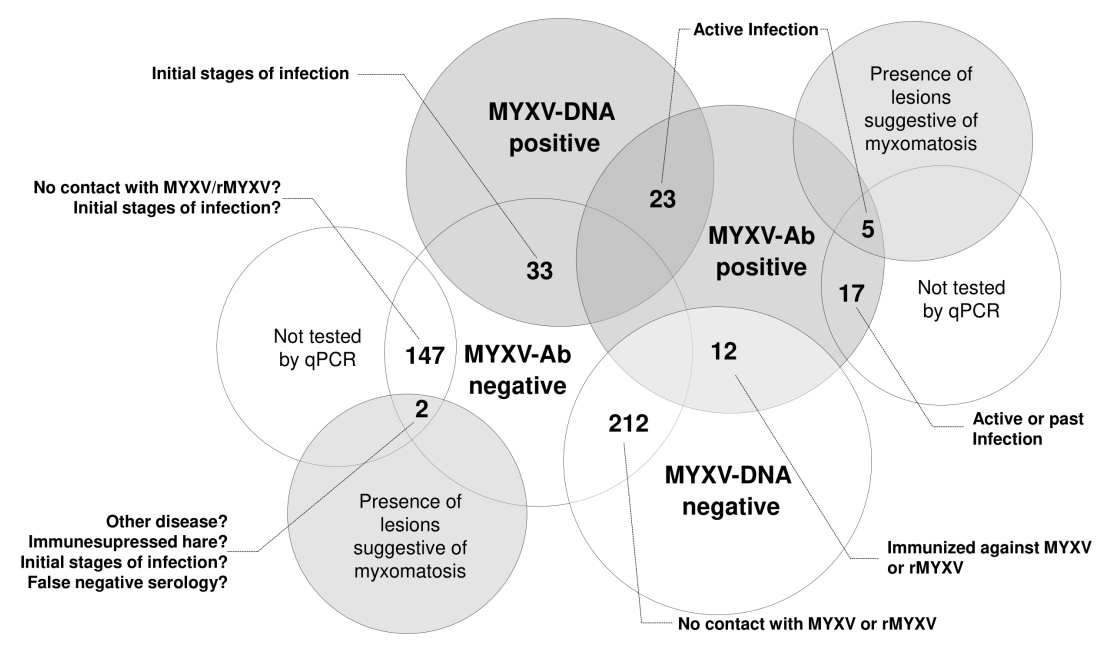


A

0,5

0,4

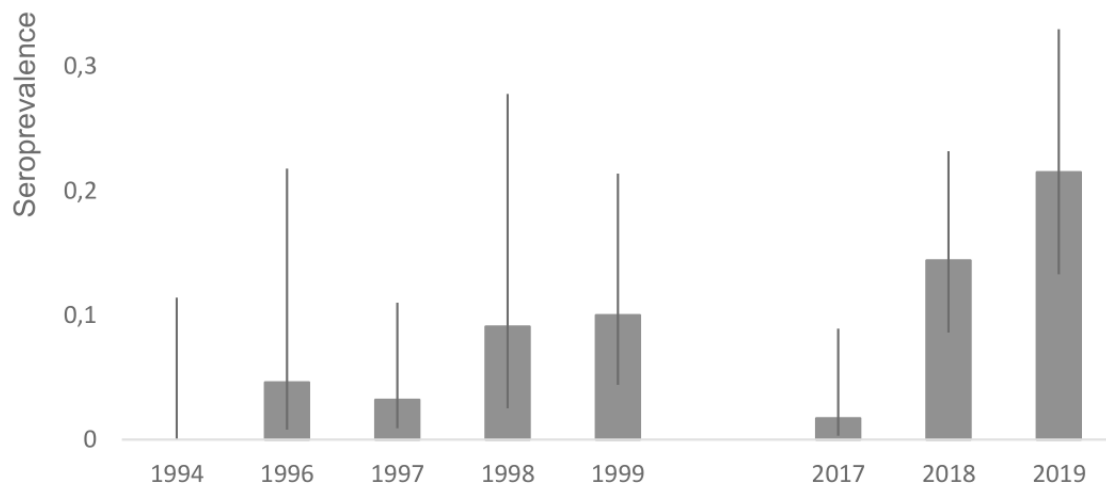

B

0,5

0,4

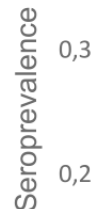

0,3

0,2

0,1

0
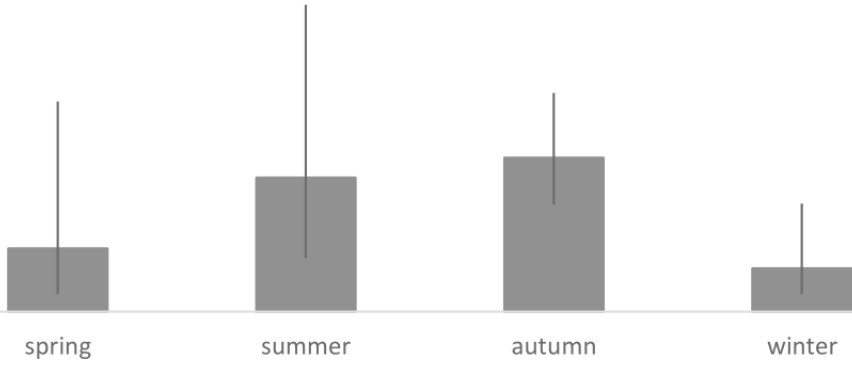

A

B
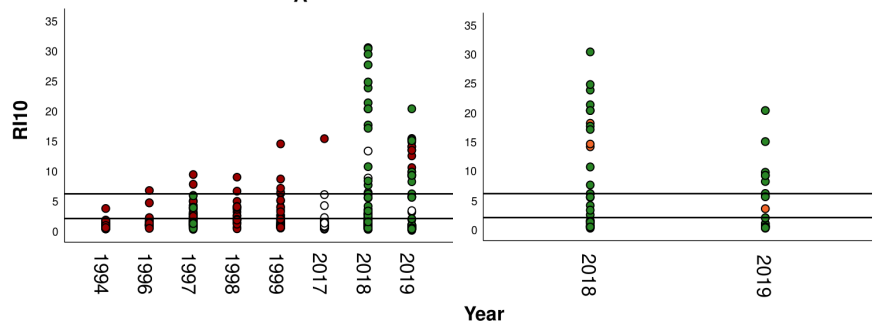

QPCR
MYXV

OM

OP 
1994-1999
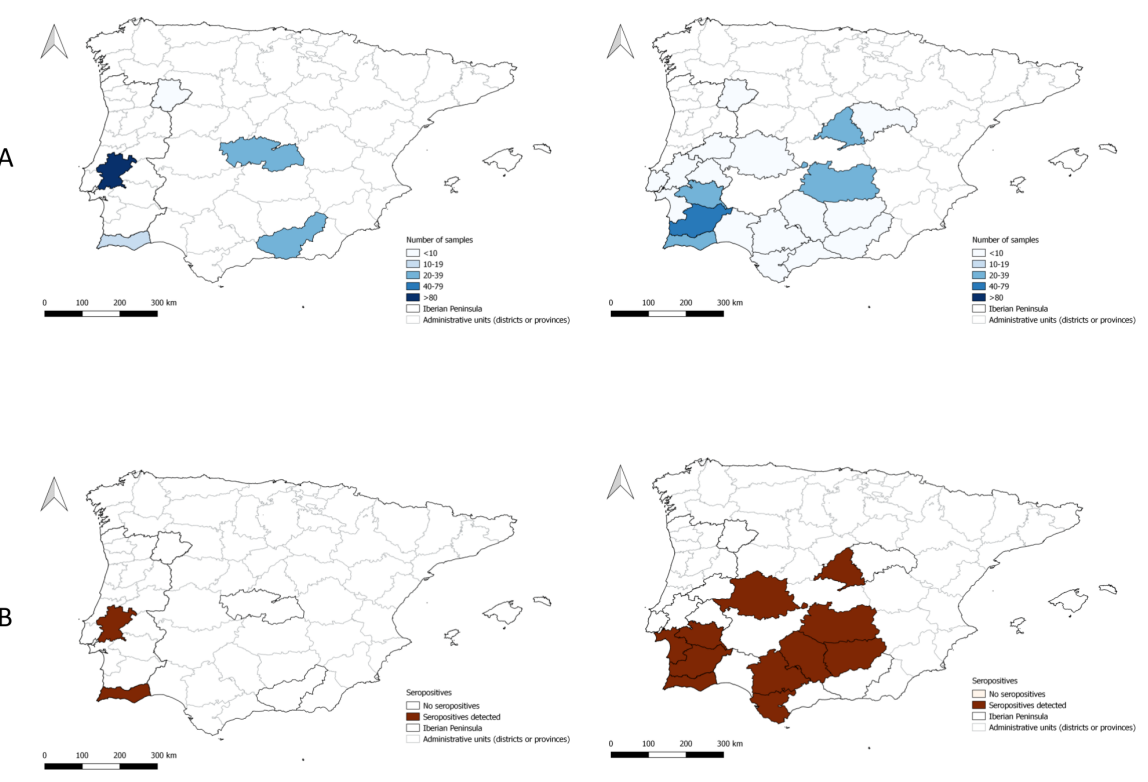

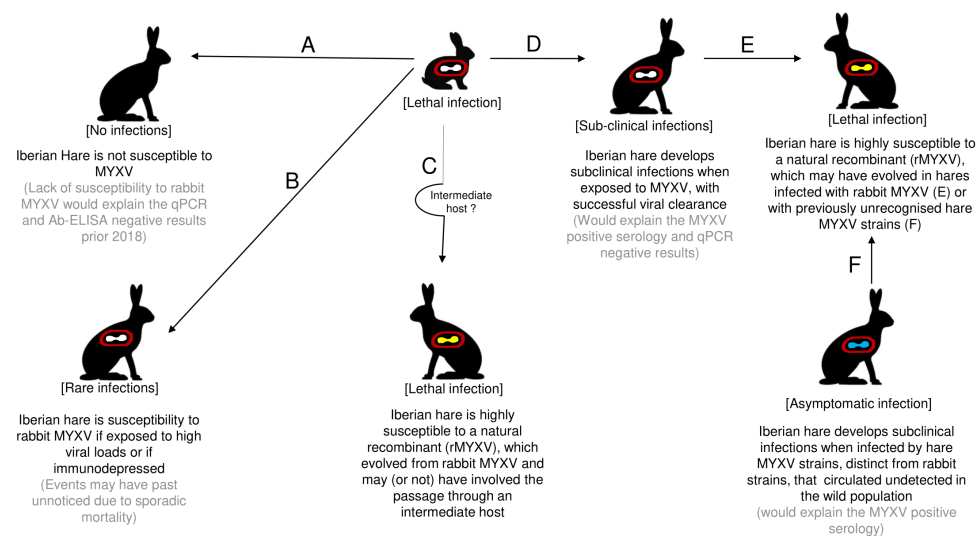

